\title{
Epizootic situation with bovine leukemia in the Central Federal District of the Russian Federation in 2012-2016
}

\author{
Alexey Gulyukin ${ }^{1 *}$, Vladimir Kuzmin ${ }^{2}$, Leonid Fogel $^{2}$ and Andrey Tsyganov ${ }^{2}$ \\ ${ }^{1}$ Federal Research Center "All-Russian Research Institute of Experimental Veterinary Medicine”, Moscow, 109428, Russia \\ ${ }^{2}$ Saint-Petersburg State University of Veterinary Medicine, Saint-Petersburg, 196084, Russia
}

\begin{abstract}
Leukemia is a chronic infectious viral disease of a tumor nature. The disease is widespread in different countries of the world and is relevant for most regions of the Russian Federation. The purpose of the work is to study the epizootic situation of leukemia in cattle in livestock farms of the Central Federal District of the Russian Federation. A complex epizootological method and evidence-based epizootology methods were used in the work. Objects of research are dysfunctional points, sick cattle. The paper presents a comparative analysis of the epizootic situation for the period 2012-2016. In the analyzed period, a total of 470 dysfunctional points for leukemia were identified, which amounted to $29.59 \%$ of the total number of dysfunctional points in the Russian Federation and 62908 animals with leukemia were registered, which amounted to $36.90 \%$ of the total number of diseased animals in Russia. Despite the decrease in the number of cattle infected with leukemia in five subjects, and the absence of animals that died from leukemia in all 18 subjects of the Central Federal District of the Russian Federation during 2012-2016, the epizootic situation of leukemia in the whole region remains quite tense, which is explained by the failure to comply with the basic requirements of the state veterinary service regarding sanitary anti-leukemia measures, according to the "Rules for the Prevention and Control of Leukemia of Large R gatogo cattle " (1999.).
\end{abstract}

\section{Introduction}

The causative agent of bovine leukemia, the RNA-containing virus, belongs to the family Retroviridae of the genus Deltaretrovirus. Pathogens of leukemia and sarcoma of cats, leukemia of birds, adenomatosis and visnamedi of sheep, infectious anemia of horses, leukemia and human immunodeficiency (HIV infection) also belong to this family. A high level of affinity was revealed between the bovine leukemia virus and the human T-cell leukemia type 1 pathogen (HTLV-1), which, in contrast to bovine leukemia virus, infects T-lymphocytes, i.e. cells that regulate the immune response [1].

A characteristic feature of retroviruses is that in most cases they do not cause the death of an infected cell. On the contrary, they constantly stimulate it, induce it to divide and activate physiological functions. All retroviruses, including the bovine leukemia virus, have common characteristic features: the presence of two biological forms - the viral (genome is represented by RNA), proviral (genome is DNA) and the ability to frequent genetic changes due to recombination [2].

The problem of leukemia as a chronic malignant viral disease of cattle is an urgent problem of veterinary medicine. Leukemia is characterized by neoplastic proliferation of hematopoietic and lymphoid tissue (lymphocytosis), the development of pathological foci of hematopoiesis (megaplasia) and a violation of the process of maturation of blood cells (anaplasia), death. Bovine leukemia is common in many countries around the world, including: in the Russian Federation, Australia, Canada, USA, Bulgaria, Croatia, Estonia, Latvia, Poland, Denmark, Romania, Ukraine, Kazakhstan and several other countries [3-5]. In the Russian Federation, the disease is a progressing epizootic in different regions of the country and age groups of animals. Leukemia, according to the severity of organ, tissue, mass manifestation, danger to the gene pool of breeding dairy cattle and economic

* Corresponding author: admin@viev.ru 
consequences, firmly takes the first place among infectious diseases of cattle - it accounts for more than $2 / 3$ of recorded cases of infectious pathology [6].

Leukemia of cattle as a new nosological disease was first established in East Prussia in animals of black-motley breed of Ostfriesian origin [3]. Enzootic leukemia is a complex infectious disease of cattle due to the lack of specific protection and treatment of animals. It has been established that the offspring of infected and hematologically ill animals with leukemia are at risk and create a long-term troubled territory for bovine leukemia [7].

The etiology of leukemia has been studied by scientists in many countries for many decades, and only in 1969, J. Miller et. al. discovered Bovine leukemia virus (BLV). In 1988, long-term experiments and analysis of literary sources allowed V.P. Shishkov to put forward a virusimmunogenetic theory of the etiology and pathogenesis of leukemia and a number of other tumor diseases in animals, which to date has been confirmed by numerous studies $[8,9]$.

The pathogen of bovine leukemia can enter the susceptible organism in two forms: infectious and proviral in the form of DNA from an infected lymphocyte. In the first case, in view of the pathogen's lymphotropicity, it infects the Blymphocyte of the new host, multiplies by budding from cytoplasmic membranes, and then integrates into cellular DNA. Being in the genetic apparatus of a eukaryotic cell (it has now been established that it can be not only a B-lymphocyte, but also a somatic mammary cell) in the form of a provirus, the pathogen spreads genetically, like ordinary cellular genes, and is a factor in the variability of the host cell genome. In the second case, the proviral form is immediately included in the genetic apparatus of the host cell [10]. Horizontal transmission is considered one of the leading ways of infection with BLV, and livestock with high proviral load is the main source of leukemia infection in the herd $[11,12]$.

To date, the social significance of the bovine leukemia virus has not been conclusively proven, but it is known that this pathogen and the human T-cell leukemia virus belong to the same genus according to the existing classification of viruses. No cases of human infection with bovine leukemia virus have been identified, but the likelihood of recombination between bovine leukemia virus and human T-cell leukemia virus is not excluded. Milk and meat from animals with leukemia animals contain metabolites of tryptophan, lysine and other cyclic amino acids that have pronounced carcinogenic properties, and therefore can be environmentally hazardous to humans, as shown by an experiment that revealed interspecific transmission of bovine leukemia virus [13].

At present, bovine leukemia is considered a disease that poses a potential danger to the gene pool of breeding dairy cattle and, in the absence of a systematic struggle, tends to increase further. The disease is widespread in many countries of the world and is relevant for most regions of the Russian Federation. The economic damage from leukemia consists of losses resulting from the culling of infected and sick animals, the disposal of carcasses, delivery of young animals from sick cows and expenses for recreational activities. The situation with the bovine leukemia in the Russian Federation requires the adoption of drastic measures [8, 14].

The purpose of the work is to study the epizootic situation of bovine leukemia in livestock farms of all forms of ownership in the Central Federal District of the Russian Federation.

\section{Materials and methods}

Objects of research - dysfunctional bovine leukemia sites in the Central Federal District of the Russian Federation, cattle that fell ill. The studied regions included Belgorod, Bryansk, Vladimir, Voronezh, Ivanovo, Kaluga, Kostroma, Kursk, Lipetsk, Moscow, Oryol, Ryazan, Smolensk, Tambov, Tver, Tula, Yaroslavl regions and the city of Moscow. To study and retrospectively analyze the epizootic situation with bovine leukemia in these 18 subjects of the Central Federal District of the Russian Federation, 
the complex epizootoliogical method was used [15], and the methods of evidencebased epizootiology [16]. Epizootiological studies in a retrospective of 2012-2016 and analysis of epizootological monitoring were carried out using materials from reporting and statistical reviews of the veterinary service for the above areas.

Diagnostic tests for bovine leukemia in all laboratory departments of the constituent entities of the Russian Federation are carried out by the serological method in the immunodiffusion reaction (RID) and the hematological method according to the "Guidelines for the diagnosis of bovine leukemia", approved by the Department of Veterinary of the Ministry of Agriculture of the Russian Federation, 2007. Of the animals that are positively responsive in RID (infected), animals infected with leukemia are identified using the hematological method [17].

\section{Results}

In the course of studying and analyzing the epizootic situation with bovine leukemia in the territory of the Central Federal District of the Russian Federation, it was found that the number of new dysfunctional points (table 1,2) in all 18 subjects of the Central Federal District in relation to their total number throughout the Russian Federation was: in $2012-43.63 \%$, in $2013-22.99 \%$, in $2014-22.47 \%$, in $2015-30.26 \%$, in $2016-40.00 \%$. A decrease in the number of leukemic dysfunctional sites in the entire Central Federal District was observed only in 2013 (by $8.88 \%$ ) and in 2014 (by
$9.40 \%)$ mainly due to the Smolensk region and the city of Moscow.

The most difficult epizootic situation for bovine leukemia in the number of dysfunctional sites was observed in the Kaluga region: 2012 - 46, 2013 - 30, 2014 - 24, 2015 - 56, 2016 - 41 points. An unfavorable epizootic situation in terms of the number of points unsuccessful for leukemia was revealed in the Tver region: 2013 - 13, 2014 - 8, 2015 - 13 points. Isolated cases of registration of dysfunctional bovine leukemia points in the analyzed period of 2012-2016 were identified in the Belgorod, Vladimir, Ivanovo, Kostroma, Tambov, Tula regions, and the city of Moscow. New dysfunctional bovine leukemia points in the analyzed period of 2012-2016 were not registered only in the Voronezh, Lipetsk and Ryazan regions (table 1,2).

The ration of sick animals (Table 1,2 ) to the number examined in the territory of 18 subjects of the Central Federal District of the Russian Federation, established during hematological studies, in relation to their total number in Russia, was: in 2012 $36.53 \%$, in $2013-34.18 \%$, in 2014 $40.08 \%$, in 2015 - $35.22 \%$, in 2016 $38.74 \%$. A slight decrease in the number of leukemia-infected cows on farms of all forms of ownership in the Central Federal District as a whole was recorded in 2012 by $0.42 \%$, in 2013 - by $2.77 \%$ and in 2015 - by $1.73 \%$. A small increase in the number of leukemia-infected cows in the Central Federal District as a whole was detected in 2014 - by $3.13 \%$ and in 2016 - by $1.79 \%$ compared to 2012.

Table 1. Epizootic situation for leukemia in cattle in the Central Federal District of the Russian Federation in 2014-2016

\begin{tabular}{|c|c|c|c|c|c|c|c|c|c|c|}
\hline \multicolumn{2}{|r|}{ Name subject } & \multicolumn{3}{|c|}{2016} & \multicolumn{3}{|c|}{2015} & \multicolumn{3}{|c|}{2014} \\
\hline & & c.z.* & s.a.* & a.d.* & c.z.* & s.a.* & a.d. $*$ & c.z.* & s.a.* & a.f.* \\
\hline \multicolumn{2}{|c|}{ Russia } & 135 & 30954 & 1 & 271 & 34202 & 32 & 405 & 37159 & 4 \\
\hline 1 & Belgorod region & & 271 & & 1 & 422 & & 5 & 382 & \\
\hline 2 & Bryansk region & & 645 & & & 575 & & 15 & 607 & \\
\hline 3 & Vladimir region & & 453 & & & 809 & & & 911 & \\
\hline 4 & Voronezh region & & 129 & & & 97 & & & 112 & \\
\hline 5 & Ivanovo region & & 194 & & 4 & 228 & & 1 & 378 & \\
\hline 6 & Kaluga region & 41 & 939 & & 56 & 630 & & 24 & 841 & \\
\hline 7 & Kostroma region & 1 & 1 & & & 2 & & 1 & 49 & \\
\hline 8 & Kursk region & & 29 & & & 24 & & 4 & 82 & \\
\hline 9 & Lipetsk region & & 694 & & & 671 & & & 823 & \\
\hline 10 & Moscow region & 6 & 4005 & & 1 & 4367 & & 13 & 5843 & \\
\hline
\end{tabular}




\begin{tabular}{|c|l|c|c|c|c|c|c|c|c|c|}
\hline 11 & Oryol Region & & 153 & & & 171 & & & 206 & \\
\hline 12 & Ryazan Oblast & & 3972 & & & 3304 & & & 3515 & \\
\hline 13 & Smolensk region & 1 & 42 & & & 25 & & 1 & 37 & \\
\hline 14 & Tambov Region & 5 & 176 & & & 157 & & 7 & 133 & \\
\hline 15 & Tver region & & 245 & & 13 & 418 & & 8 & 630 & \\
\hline 16 & Tula region & & 6 & & 3 & 30 & & 3 & 110 & \\
\hline 17 & Yaroslavskaya oblast & & 2 & & 3 & 12 & & 9 & 23 & \\
\hline 18 & Moscow city & & 35 & & 1 & 103 & & & 213 & \\
\hline TOTAL & $\mathbf{5 4}$ & $\mathbf{1 1 9 9 1}$ & & $\mathbf{8 2}$ & $\mathbf{1 2 0 4 5}$ & & $\mathbf{9 1}$ & $\mathbf{1 4 8 9 5}$ & \\
\hline
\end{tabular}

Table 2. Epizootic situation for leukemia in cattle in the Central Federal District of the Russian Federation in 2012-2013

\begin{tabular}{|c|c|c|c|c|c|c|c|}
\hline \multirow{2}{*}{\multicolumn{2}{|c|}{$\begin{array}{l}\text { Name } \\
\text { subject }\end{array}$}} & \multicolumn{3}{|c|}{2013} & \multicolumn{3}{|c|}{2012} \\
\hline & & C.Z. ${ }^{*}$ & s.a.* & a.d.* & C.z. ${ }^{*}$ & s.a.* & a.d.* \\
\hline \multicolumn{2}{|r|}{ Russia } & 461 & 39061 & 13 & 314 & 29083 & 12 \\
\hline 1 & Belgorod region & & 353 & & & 85 & \\
\hline 2 & Bryansk region & 11 & 564 & & 1 & 63 & \\
\hline 3 & Vladimir region & 3 & 962 & & 2 & 781 & \\
\hline 4 & Voronezh region & & 34 & & & & \\
\hline 5 & Ivanovo region & 1 & 326 & & 3 & 431 & \\
\hline 6 & Kaluga region & 30 & 963 & & 46 & 1070 & \\
\hline 7 & Kostroma region & 2 & 179 & & 2 & 41 & \\
\hline 8 & Kursk region & 15 & 279 & & 3 & 237 & \\
\hline 9 & Lipetsk region & & 231 & & & 151 & \\
\hline $\begin{array}{l}1 \\
0\end{array}$ & Moscow region & 6 & 5508 & & 25 & 5432 & \\
\hline $\begin{array}{l}1 \\
1 \\
\end{array}$ & Oryol Region & & 480 & & 24 & 438 & \\
\hline $\begin{array}{l}1 \\
2\end{array}$ & Ryazan Oblast & & 1813 & & & 748 & \\
\hline $\begin{array}{l}1 \\
3\end{array}$ & Smolensk region & 12 & 75 & & 25 & 186 & \\
\hline $\begin{array}{l}1 \\
4\end{array}$ & Tambov Region & 1 & 96 & & & & \\
\hline $\begin{array}{l}1 \\
5\end{array}$ & Tver region & 13 & 720 & & & 242 & \\
\hline $\begin{array}{l}1 \\
6\end{array}$ & Tula region & & 229 & & & 278 & \\
\hline $\begin{array}{l}1 \\
7\end{array}$ & $\begin{array}{l}\text { Yaroslavskaya } \\
\text { oblast }\end{array}$ & 1 & 8 & & 1 & 5 & \\
\hline $\begin{array}{l}1 \\
8 \\
\end{array}$ & Moscow city & 4 & 533 & & 5 & 436 & \\
\hline \multicolumn{2}{|c|}{ TOTAL } & 106 & 13353 & & 137 & 10624 & \\
\hline
\end{tabular}

Note: c.z.* - contamination zone (newly identified)

s.a.* - sick animals, a.d.*- animals dead.

An unfavorable epizootic situation with an increase in the number of animals infected with leukemia was observed during the entire analyzed period in the Belgorod Region (in 2015 it was 4.98 times higher than in 2012), the Bryansk region (in 2016 it was 10.24 times higher than in 2012), the Voronezh region (in 2016 it was 3.79 times higher than in 2013), the Lipetsk region (in 2016 it was 4.60 times higher than in 2012). in the Tambov region - (in 2016 it was 1.83 times higher than in 2013). It should be noted that in the
Ryazan region the number of animals infected with leukemia in 2016 was 5.31 times higher than in 2012 against the background of the complete absence of newly identified dysfunctional leukemia points in the analyzed period.

Fluctuations in the number of animals affected by leukemia from the number of cattle examined in the subjects of the Central Federal District of the Russian Federation in the context of the analyzed period

2012-2016 (Table 1,2) were observed in: 
Kaluga region (in heads): in 2012 - 1070, in 2015 - 630 , in 2016 - 939; Moscow Region (in heads): in 2012 - 5432, in 2014 - 5843, in 2016 - 4005; Tver region (in heads): in 2012 - 242, in 2013 - 720, in 2016 - 245; Yaroslavl region (in heads): in 2012 - 5, in $2014-23$, in 2016 - 2.

A decrease in the ratio of cows with leukemia from the number of animals examined in the subjects of the Central Federal District of the Russian Federation (Table 1,2) was recorded in the Ivanovo Region - in 20162.22 times less than in 2012; in the Kostroma region - in 2016 179.00 times less than in 2013; in the Smolensk region - in 20157.44 times less than in 2012; in the Tula region - in 2016, 46.33 times less than in 2012; in the city of Moscow - in 2016 it is 15.23 times less than in 2013.

\section{Discussion}

Over the past decade, in many countries of the world and in various constituent entities of the Russian Federation (including the Central Federal District), the spread of leukemia has retained significant proportions that seriously threaten the development of dairy cattle farming. Significant damage to livestock caused by bovine leukemia is caused by premature culling; a decrease in the quality of products obtained from sick animals; loss of breeding value of animals due to suppression of the immune system by the causative agent of leukemia; decreased resistance to infectious and noncommunicable diseases; expenses for recreational activities [4, 18-20].

The difficulty in solving the problem of bovine leukemia is associated with the existence of the pathogen of bovine leukemia in both viral and proviral forms; his ability to frequent mutations; lack of treatment and active prevention of leukemia; the lack of complete data on the causes and mechanisms causing uncontrolled proliferation of lymphoid cells with a violation of their maturation; the lack of reliable data on the causes and mechanisms of activation of the infectious process, when there is a long or life time period between infection and a possible disease [10, 21].

Unfortunately, at present, practical veterinary medicine is unlikely to radically solve these problems. In this regard, today the prevention and control of bovine leukemia is based on the strict and timely implementation of a set of measures to protect successful herds from the introduction of the pathogen, identifying and removing animals and bovine leukemia virus-infected animals, depending on the state of the epizootic situation in economy $[5,9]$.

We analyzed the epizootic situation with bovine leukemia in the Central Federal District of the Russian Federation in 20122016, taking into account the number of dysfunctional points, the number of sick and dead animals.

In 2012-2016, a total of 470 dysfunctional bovine leukemia points were identified in the Central Federal District, which amounted to $29.59 \%$ of the total number of dysfunctional points in the Russian Federation. A decrease in the number of cattle leukemic dysfunctional sites in farms of all forms of ownership in the Central Federal District was observed only in 2013 (by $8.88 \%$ ) and in 2014 (by $9.40 \%)$ mainly due to the Smolensk region and the city of Moscow. The most unfavorable epizootic situation in the number of dysfunctional bovine leukemia points was observed in the Kaluga Region (table 1, 2). Newly identified items identified dysfunctional bovine leukemia points were not registered in the analyzed period of 2012-2016 only in the Voronezh, Lipetsk and Ryazan regions.

Using diagnostic hematological tests for bovine leukemia in 2012-2016, a total of 62.908 diseased animals were identified in the Central Federal District, which amounted to $36.90 \%$ of the total number of sick animals in the Russian Federation.

In five constituent entities of the Central Federal District, a decrease in the number of animals infected with leukemia from the number examined in the analyzed period 2012-2016 in the Ivanovo region was recorded by 2.22 times; in the Kostroma region - 179.00 times; in the Smolensk 
region - 7.44 times; in the Tula region 46.33 times; in the city of Moscow - 15.23 times. Also, the absence of animals that died from leukemia in all 18 regions of the Central Federal District of the Russian Federation during 2012-2016 was found.

Despite the decrease in the number of animals infected with leukemia in the above five subjects, the epizootic situation in bovine leukemia in the Central Federal District as a whole remains quite tense, which indicates the failure to comply with the requirements / recommendations of the state veterinary service.

The most unfavorable epizootic situation in terms of the number of sick cattle developed in the Bryansk, Ryazan, Kaluga, Lipetsk, Vladimir, Moscow regions. So, the number of animals infected with leukemia increased by 2016 compared to 2012 in the Bryansk region - 10.24 times; in the Ryazan region - by 5.31 times.

Despite the decrease in the number of animals infected with leukemia in the above five subjects, the epizootic situation in bovine leukemia in the Central Federal District as a whole remains tense, which indicates the failure to comply with certain requirements of the state veterinary service during the herd rehabilitation.

According to the data of the Federal State Budgetary Institution "Center for Veterinary Medicine" for 2016, "the very tense epizootic situation for leukemia continues to remain in the Novosibirsk, Chelyabinsk, Kaluga, Kurgan, Tver, Moscow regions, and the Krasnodar Territory. In 2016, 41 new dysfunctional sites were identified in the Kaluga Region, 939 cattle fell ill "[cit. to 22]. This information is fully consistent with our results on the analysis of the epizootic situation in bovine leukemia in 2012-2016 in the Kaluga, Tver, Moscow regions, presented in Table 1, 2.

In most European countries, as well as in some regions of the Russian Federation, effective programs for the eradication of leukemia are successfully implemented, for example, in the Leningrad region [23], in the Smolensk region [14], and also in the Sverdlovsk, Vologda and several other areas. At the same time, the levels of infection of animals with leukemia virus and the incidence of leukemia throughout the world are still high [24]. Analysis of epizootological data for different subjects of the Central Federal District in a retrospective of 2012-2016 showed that among the studied 18 regions there is not a single subject that is favorable for bovine leukemia.

In recent years, the scope of scientific research has expanded significantly and new data have been obtained on the organization of preventive and antiepizootic measures that allow the effective use of a system of therapeutic antileukemia measures depending on the degree of damage to the dysfunctional herd, including through the replacement of cattle breeds with leukemia-resistant $[7,13$, 24-27]. However, the existing systems of antiepizootic measures are far from perfect and require scientific and industrial development, taking into account the regional epizootological features of bovine leukemia.

Based on the analysis of the state of the epizootic situation in bovine leukemia and taking into account the shortcomings in the work of managers and veterinarians in farms of all forms of ownership in the Central Federal District of the Russian Federation during the rehabilitation of farms in this region, we recommend reviewing the "Prevention and the fight against leukemia in cattle "(1999) [25] and addtion of the following provisions: on increasing the responsibility of producers of dairy and meat products for noncompliance the adoption of the requirements of the state veterinary service regarding recreational anti-leukemia measures; on increasing the responsibility of veterinary services for the reliability of reporting information.

\section{Conclusions}

1. The epizootic situation with bovine leukemia in farms of all forms of ownership in the territory of the Central Federal District of the Russian Federation in 20122016 was analyzed, taking into account the number of dysfunctional points, the number of sick and dead animals. 
2. In 2012-2016, a total of 470 dysfunctional bovine leukemia points were identified in the Central Federal District, which amounted to $29.59 \%$ of the total number of dysfunctional points in the Russian Federation. A decrease in the number of leukemic dysfunctional sites in the entire Central Federal District was observed in 2013 (by $8.88 \%$ ) and in 2014 (by $9.40 \%$ ) mainly due to the Smolensk region and the city of Moscow. The tense epizootic situation of bovine leukemia, taking into account the number of dysfunctional points during the entire analyzed period, was revealed in the Kaluga Region with a minimum number of dysfunctional points in $2014-24$ and a maximum number in 2015 - 56 points. Voronezh, Lipetsk, Ryazan regions did not have fresh dysfunctional bovine leukemia points in the analyzed period of 20122016.

3. In 2012-2016, a total of 62,908 animals with leukemia of animals were identified in the Central Federal District of the Russian Federation, which amounted to $36.90 \%$ of the total number of sick animals in the Russian Federation. An unfavorable epizootic situation in terms of the number of sick cattle developed in the Bryansk, Ryazan, Kaluga, Lipetsk, Vladimir, and Moscow regions. The number of animals infected with leukemia increased by 2016 compared to 2012 in the Bryansk region 10.24 times, in the Ryazan region - 5.31 times.

4. Despite the decrease in the number of animals infected with leukemia in the households of five subjects of the Central Federal District of the Russian Federation from 2012 to 2016 (Ivanovo, Kostroma, Smolensk, Tula regions, the city of Moscow), and the absence of animals in all 18 subjects, dead from leukemia, the epizootic situation of bovine leukemia as a whole in the Central Federal District remains quite tense.

5. We recommend revising the "Rules for the Prevention and Control of Bovine leukemia" (1999) and adding the provisions on increasing the responsibility of producers of dairy and meat products for failure to comply with the requirements of the state veterinary service regarding recreational anti-leukemia measures; on increasing the responsibility of veterinary services for the reliability of reporting information.

\section{References}

1. Y. Aida, H. Murakami, M. Takahashi, S.N. Takeshima, Mechanisms of pathogenesis induced by bovine leukemia virus as a model for human T-cell leukemia virus, Front. Microbiol., 4, 328 (2013) DOI: 10.3389/ fmicb.2013.00328

2. I. Alvarez, G. Gutierrez, M. Gammella, C. Martinez, R. Politzki, C. Gonzalez et al., Evaluation of total white blood cell count as a marker for proviral load of bovine leukemia virus in dairy cattle from herds with a high seroprevalence of antibodies against bovine leukemia virus, Am. J. Vet. Res., 74(5), 744749 (2013) DOI: 10.2460/ajvr.74.5.744

3. V.N. Syurin, A.Ya. Samuilenko, B.V. Solovyov, N.V. Fomina, Leukemia cattle, In Viral diseases of animals (Moscow, 2001) pp. 383-407

4. M. LaDronka, R.S. Ainsworth, M.J. Wilkins, B. Norby et al., Prevalence of bovine leukemia virus antibodies in US dairy cattle, Vet. Med. Int., 83, 1278 (2018) DOI: 10.1155/2018/5831278

5. A. Rudy, K. Ploneczka, Eradication of bovine leukaemia in Poland, Med. Weter., 63(6), 648-650 (2007)

6. N.G. Kozyreva, M.I. Gulyukin, Distribution of bovine leukemia and genetic variants of the pathogen on the territory of livestock farms of the Central Federal District of the Russian Federation, Veter. of Kuban, 6, 4-9 (2017)

7. M.A. Juliarena, C.N. Barrios, C.M. Liitzelschwab et al., Bovine leukemia virus: current perspectives, Virus Adaptat. and Treatment., 9, 13-26 (2017) DOI: 10.2147/VAAT.S113947

8. O.A. Verkhovsky, T.I. Aliper, Leukemia cattle, in: Virology Guide: Human and Animal Viruses and Viral Infections (Moscow, 2013) pp. 869-873

9. G.G. Novoseltsev, Features of the manifestation of enzootic leukemia in cattle and the improvement of anti-epizootic measures, Cand. Dissertation (Stavropol, 2013) 128 p.

10. C.J. Panei, S.N. Takeshima, T. Omori, T. Nunoya, W.C. Davis, H. Ishizaki et al., Estimation of bovine leukemia virus (BLV) proviral load harbored by lymphocyte subpopulations in BLV-infected cattle at the subclinical stage of enzootic bovine leucosis using BLV-CoCoMo-qPCR, BMC Vet. Res., 9, 95 (2013) DOI: 10.1186/1746-6148-9-95

11. H. Mekata, S. Sekiguchi, S. Konnai, Y. Kirino, Y. Horii, J. Norimine, Horizontal transmission and phylogenetic analysis of bovine leukemia virus in two districts of Miyazaki, Japan. J. Vet. Med. Sci., 
77(9), 1115-1120 (2015) DOI: 10.1292/jvms.140624

12. H. Mekata, S. Sekiguchi, S. Konnai, Y. Kirino, K. Honkawa, N. Nonaka et al., Evaluation of the natural perinatal transmission of bovine leukaemia virus, Vet. Rec., 176(10), 254 (2015) DOI: 10.1136/vr. 102464

13. V.A. Mishchenko, O.N. Petrova, A.K. Karaulov, A.V. Mishchenko, The problem of leukemia in cattle (Vladimir, 2018) $38 \mathrm{p}$.

14. N.I. Tselueva, I.M. Kugelev, N.G. Myasnikov, Analysis of the epizootic situation of leukemia in cattle in the Smolensk region, Veter. Med., 10, 11-14 (2017)

15. V.V. Sochnev, Yu.V. Pashkina, O.V. Kozyrenko et al., Evidence-based epizootology (research methodology), Monograph (Nizhny Novgorod, 2016) $160 \mathrm{p}$.

16. V.V. Makarov, A.V. Svyatkovsky, V.A. Kuzmin, O.I. Sukharev, Epizootological research method (St. Petersburg, 2009) $224 \mathrm{p}$.

17. Guidelines for the diagnosis of leukemia in cattle, Approved by the Department of Veterinary Medicine of the Ministry of Agriculture of the Russian Federation (2007)

18. V.A. Apalkin, M.I. Gulyukin, N.I. Petrov, Leukemia cattle (St. Petersburg, 2005) $105 \mathrm{p}$.

19. P.N. Smirnov, I.V. Trostyansky, S.M. Chydym, M.A. Leonova, M.A. Amirokov, Leukemoid reactions in cattle: causes, nature of manifestation and seasonal dynamics, Innovat. and food security, 4(18), 51-55 (2017)
20. P.N. Smirnov, V.V. Khramtsov, S.N. Mager, V.V. Razumovskaya, M.A. Amirokov, I.V. Tyunkov, Immunomorphological changes accompanying the development of human and animal hemoblastoses, Innovat. and food security, 4(18), 39-50 (2017)

21. M.A. Juliarena, S.E. Gutierrez, C. Ceriani, Determination of proviral load in bovine leukemia virus-infected cattle with and without lymphocytosis, Am. J. Vet. Res., 68(11), 1220-1225 (2007) DOI: 10.2460/ajvr.68.11.1220

22. Leukemia cattle registered in 71 regions of Russia, The Dairy News (23 July 2020) Retrieved from: https://www.dairynews.ru/news/leykoz-krszaregistrirovan-v-71-regione-rossii.html

23. M.I. Gulyukin, A.A. Stekolnikov, V.A. Kuzmin, L.S. Vogel, Bovine Leukemia is a managed disease, Veter. Med., 9, 9-14 (2013)

24. K. Murakami et al., The recent prevalence of bovine leukemia virus $(B L V)$ infection among Japanese cattle, Vet. Microbiol., 148(1), 84-88 (2011)

25. Rules for the prevention and control of bovine leukemia, Approved by order of the Ministry of Agriculture and Food of the Russian Federation of 05.11.1999, no. 359

26. V. Ruiz, N.G. Porta, M. Lomonaco, K. Trono, I. Alvarez, Bovine leukemia virus infection in neonatal calves. Risk factors and control measures, Front. Vet. Sci., 5, 267 (2018) DOI: 10.3389/fvets.2018.00267

27. M. Polat, S.-N. Takeshima, Y. Aida, Epidemiology and genetic diversity of bovine leukemia virus, Virol. J., 14(1), 209 (2017) DOI: 10.1186/ sl2985017-0876-4 